\title{
18
}

\section{Learning from Others: Considerations within History Didactics on Introducing the Cold War in Lessons in Germany, Sweden and Switzerland}

\section{Peter Gautschi and Hans Utz}

Every beginning is hard, yet, as the saying goes, well begun is half done. As regards getting things started, we could use a number of other aphorisms, and almost all of them emphasise the significance of the beginning. That holds true in the context of teaching as well, since here the start of a lesson or topic, in fact, constitutes a key phase and is plannable like no other teaching situation (Gautschi 2012, 114-117). It is particularly difficult to begin teaching the topic of the Cold War, because there does yet not exist any unanimously accepted master narrative about it (Furrer and Gautschi 2017, 16-21).

How, then, does history teaching on the Cold War begin? We compare the introductory lessons on the topic of the Cold War in four school classes, one in the former East Germany, one in the former West Germany,

P. Gautschi $(\bowtie)$

Institute for History Education and Memory Cultures, University of Teacher Education Lucerne, Lucerne, Switzerland e-mail: peter.gautschi@phlu.ch

H. Utz

University of Teacher Education Lucerne, Lucerne, Lucerne, Switzerland e-mail: hans.utz@phlu.ch 
one in Switzerland and one in Sweden. This comparison allows us, firstly, to identify the similarities and differences between the observed lessons. Secondly, the teaching settings which are actually realised in these classrooms can be compared with possible alternatives, on the basis of considerations guided by theory. Thirdly, criteria can be proposed and applied ${ }^{1}$ which allow us to judge how successfully each chosen introduction to each of the four lessons ensures historical learning.

This chapter intends to draw teachers' attention to different ways of introducing topics in history lessons and to generally encourage teachers to reflect on their own role in teaching history lessons. At the same time, it is aimed at scientists who observe, analyse and interpret history teaching. It will provide them with theories and possible approaches for discussion, and is structured around three sets of basic questions concerning history didactics: What issues and debates do teachers tackle in introductory lessons on the Cold War? What subjects, terminology, concepts and narratives are discussed? What perspectives do teachers approach past events from? The second set of questions allows us to ask: How are these perspectives related? How do teachers design their lessons? What processes and structures do they use and what forms of teaching, learning opportunities and presentation concepts are offered? Finally, we introduce the following questions: What purpose does this method of teaching serve? What new knowledge and skills will students acquire and what are the opinions and attitudes that they will build up and be able to differentiate between?

\section{Learning Subjects: The 'What?' of History Teaching}

While the topic 'the Cold War' can be covered in many different school subjects, three particular aspects render this topic a learning subject for history teaching: (a) If development contexts, meaning the causes and effects of the event and continuity and change over the course of time, are discussed. The teacher might ask what happened before and after the event, and what the reasons for and consequences of the phenomenon were. (b) The Cold War also becomes a topic for history education if individuals' actions and issues of identity are explored, especially in regard 
to social practice concerning rule, economy and culture. Who acted? Who had to bear the consequences? How do past events concern different groups of people? Finally (c), the topic becomes relevant for the history classroom if concrete examples, methods and principles of historical knowledge are included in the lesson. What are the findings from the sources? Are there any contradictory sources and representations? How does historiography differentiate between the memories of people involved in the event and the current objectivities of historical and memory cultures? (Gautschi and Fink 2016, 138-140). One and the same subject can be taught in radically different ways. In other words: With respect to the 'what?' of history teaching, the narratives presented and tackled in these lessons are thus of particular interest (Mayer 2005, 223-228).

\section{Development Contexts}

Whoever wants to document, characterise and analyse the 'what?' of history teaching, first of all, must record the chronological markers which can be found in teaching. It is particularly important to note whether the date, duration and sequence of events and processes are precisely laid out and how changes are depicted. For example, the teacher in the lesson taking place in Lower Saxony refers back to the Russian Revolution when explaining the prehistory of the Cold War:

02:04 Tf In that time there was, however, a war against Japan in 1905 in which the Russians were without much ado defeated. This was the trigger for more and more violent protests in the cities. So that certain reforms were initiated, but [...] in 1914 war broke out from the part of Russia and from the part of Germany. And the reforms for the time being got stuck again.

The causes and consequences of the event being taught also need to be identified in historical development contexts. Indicators for these are word particles like 'afterwards', 'therefore', 'eventually', 'thus' or 'because' which are, for example, used by a student in Saxony-Anhalt: 
21.09 PmA Yes, there were no active actions happening between both the powers because they knew that they both were very strong, they were in possession of nuclear arms. Thus, the deterrence was, in fact, also mutual since they knew that if they now started a war, perhaps also the world or a Third World War, that they were not going to survive it. And, therefore, these acts of war did, in fact, partly not happen either. And then, the situation was actually so tense because they had partly also provoked each other. But, in fact, they knew that the deterrence actually existed.

If one compares to what extent development contexts occur in the four lessons the following picture emerges:

Fig. 18.1 shows that the date, duration and sequence of events and processes can generally be designated precisely. In almost all cases, we can see that the emergence of the two 'fronts' of the Cold War, after their alliance in the Second World War, is clearly explained and the histories of the USA and the Soviet Union contrasted. Only in the Swedish lesson is the focus more strongly put on people's everyday experience in Sweden during this period. The lesson in Lower Saxony stands out because of the

\begin{tabular}{|c|c|c|c|c|c|}
\hline & \multirow[t]{2}{*}{-} & \multirow[b]{2}{*}{0} & \multirow{2}{*}{\begin{tabular}{|l|}
+ \\
$\mathbf{O X}$
\end{tabular}} & \multirow[t]{2}{*}{++} \\
\hline \multirow{6}{*}{$\begin{array}{l}\text { 1. Scheme of } \\
\text { changes over time } \\
\text { and of development } \\
\text { contexts }\end{array}$} & $\begin{array}{l}\text { a. The description of the date, duration, } \\
\text { sequence of events and processes is } \\
\text { precise. }\end{array}$ & & & & \\
\hline & b. Changes are depicted. & & $\mathbf{O}$ & $\mathrm{XO}$ & $\nabla$ \\
\hline & $\begin{array}{l}\text { c. The differences of phenomena in } \\
\text { different time periods are delineated. }\end{array}$ & & oox & & \\
\hline & $\begin{array}{l}\text { d. Possible alternative courses of } \\
\text { events are depicted. }\end{array}$ & $\diamond 0$ & X & & \\
\hline & $\begin{array}{l}\text { e. Causes, preconditions of events and } \\
\text { actions are explored. }\end{array}$ & & $\mathbf{O}$ & OX & 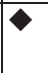 \\
\hline & $\begin{array}{l}\text { f. Consequences, effects of events and } \\
\text { actions are described. }\end{array}$ & & OX & 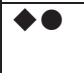 & \\
\hline
\end{tabular}

Key: -: not true, 0 : just true, + : very true, ++ : pronouncedly true

Fig. 18.1 Table of the Scheme of Changes over Time and of Development Contexts (Gautschi 2012, 97); Lower Saxony ( $\bullet$ ), Saxony-Anhalt (O), Sweden ( $(\bullet)$, Switzerland (X) 
fact that causes as well as preconditions of events and actions are clearly delineated. It is surprising that, in these introductory lessons, teachers don't touch upon the possible results of the Cold War, or what might have happened had the superpowers not come to an agreement with the intervention of the United Nations. Here the students can imagine how different the results of the Cold War could have been.

\section{Human Action in Social Practice}

The central subject of history is the individual human agent, inescapably bound in the structural contexts of the time period within which they live. Whoever wants to investigate the 'what?' of history teaching thus, for example, must therefore ask how people and institutions are represented. Who is described as the actor, who as the sufferer? The teacher from Sweden, for example, presents herself and her parents as contemporary witnesses to the period right at the beginning of the lesson:

02:50 Tf [I say] that I was born in 1959. Thirty years I was thus living in a historical epoch which is called 'the Cold War'. Your parents as well and especially my mother and parents are really marked by this time period.

Furthermore, it is interesting to note the areas of meaning formation which become subjects of discussion in the process of teaching the Cold War. According to Hans-Ulrich Wehler by areas of meaning formation the three equal, continuously ongoing dimensions of society are meant: rule, economy and culture $(2006,7)$. Of course, the Cold War can be dealt with from political perspectives and approached from different viewpoints in class. But economic and cultural issues also play an important role especially when it comes to this particular topic.

An analysis of these lessons makes clear that in the introductory lessons in Switzerland, in Sweden and in Lower Saxony humans become particularly visible as actors (Stalin, Roosevelt, Churchill and others, for example), as well as emphasising the idea that the Cold War is best dealt with from political viewpoints, seen as a conflict which emerged because 


\begin{tabular}{|l|l|l|l|l|l|}
\cline { 3 - 6 } \multicolumn{2}{l|}{} & - & 0 & + & ++ \\
\hline $\begin{array}{l}\text { 2. Thematisation of } \\
\text { human action in } \\
\text { social practice. }\end{array}$ & $\begin{array}{l}\text { a. Humans are visible as actors. } \\
\text { b. Rule and participation are } \\
\text { thematised. }\end{array}$ & & - & $\checkmark \mathbf{X O}$ & \\
\cline { 2 - 6 } & $\begin{array}{l}\text { c. } \text { Poverty and wealth as well as work } \\
\text { are thematised. }\end{array}$ & $\mathbf{O O X}$ & - & & \\
\cline { 2 - 6 } & d. Culture is thematised. & OOX & $\bullet$ & & \\
\hline
\end{tabular}

Key: -: not true, 0 : just true, + : very true, ++ : pronouncedly true

Fig. 18.2 Table of Evaluation of the Thematisation of Human Action in Social Practice in Four Introductory Lessons on the Cold War; Lower Saxony $(\diamond)$, SaxonyAnhalt (O), Sweden $(\bullet)$, Switzerland $(X)$

of a contrast between two worldviews (see Fig. 18.2). Surprisingly enough, within these lessons, economic and cultural factors are practically ignored. However, popular songs from both camps, historical monuments, comics or the recorded memories of ordinary people about their youth in the East and the West, that is to say relevant cultural artefacts, for example, would be useful as starting points when introducing the topic of the Cold War, and perhaps would generate more interest among students.

\section{Principles and Methods of Historical Knowledge}

In order to teach the topic of the Cold War in history lessons in particular teachers must both carefully select content and also present methods and principles of approaching historical knowledge. Since the past is past and cannot be directly observed, because history is thus always constructed, the examination of the validity of these constructions is an important task. At the same time, whenever possible controversial sources and multi-perspectival representations need to be consulted (Pandel 2006, 16). As regards the topic of the 'Cold War', this is often very well achieved in the observed lessons, with the exception of the Swedish lesson, as the following excerpt from the Swiss lesson illustrates: 


\begin{tabular}{|l|l|l|l|l|}
\cline { 2 - 6 } \multicolumn{1}{l|}{} & - & 0 & + & ++ \\
\hline 3. Exemplary and target-group-adjusted representations & $\mathbf{O}$ & $\bullet$ & $\mathbf{X} \boldsymbol{}$ & \\
\hline 4. Validity, multi-perspectivity, controversy & & - & $\mathbf{O}$ & $\bullet \mathbf{X}$ \\
\hline 5. Reference to the present & & & $\bullet \mathbf{O O X}$ & \\
\hline 6. Reference to the learners' living environments & & $\bullet \mathbf{O O X}$ & & \\
\hline 7. Methods of historical knowledge & $\mathbf{O}$ & $\bullet \mathbf{X} \bullet$ & & \\
\hline
\end{tabular}

Key: -: not true, 0 : just true, + : very true, ++ : pronouncedly true

Fig. 18.3 Table of Evaluation of Principles and Methods of Acquiring Historical Knowledge in Four Introductory Lessons on the Cold War; Lower Saxony $(\diamond)$, Saxony-Anhalt (O), Sweden (O), Switzerland (X)

33:34 Tf Well, your task is the following: In the book there is a source by Truman, the American president who talks about the Soviet Union, and there is a source by Zhdanov, the secretary of the Central Committee. And it is your task, that means somebody adopts the role of Truman, somebody the role of Zhdanov, and you work out the core messages of this source and you will try and convince the other of what, in fact, is good about Communism or likewise Capitalism.

Teachers can better ensure that their students acquire historical knowledge if references to the present and the living environment are provided and if the dealing with sources, representations and historico-cultural factors follows methodological rules which can be taught and learned. As Fig. 18.3 shows the four lessons are similar in that all of them hardly make any mention of living environments but do make reference to the present. With a view to the other criteria, differences are rather stark.

\section{Core Content of the Introductory Lessons}

Whereas the criteria discussed so far allow for interesting comparisons about the learning subject, they do not expound at all upon narrative meaning formation. If we refer back to the concept of 'narrative templates', a term coined by James V. Wertsch (2008, 133-156), we can see just how important this understanding is. According to Wertsch, narrative templates differ from 'formal history' as they make use of 'templates' at two 
levels: 'Specific narrative templates' contain concrete data-supported (not necessarily objective, scientific-based) messages which give their validity to a narrative through concrete events. 'Schematic narrative templates' are based on universal convictions shared by the narrator as well as the addressee. These convictions establish a connection between individual events in a narrative, which reveals itself to the addressees even when the explanation lacks detail.

If we compare the four lessons by referring back to the narrative templates used each time, we discover startling similarities with regard to the 'schematic narrative templates', which can be summarised in four points made by the teachers: Firstly, a common enemy brings two entities together in an attempt to overwhelm that enemy with joint forces. Secondly, in each lesson the teacher poses the question of whether indeed such a union can be achieved, pointing to how, afterwards, the differences between the two forces prevail once again, causing conflict. Thirdly, the teachers argue that, because the two forces do not want to have another conflict after the first, they distance themselves from each other. The fourth point the teachers make, which accords with this 'schematic narrative template', is that, instead of a violent fight with severe losses, an indirect, dogged, 'cold' conflict breaks out, namely the Cold War. This 'schematic narrative template' dates back to a post-revisionist interpretation of the Cold War, according to which neither the Soviet Union nor the USA can unequivocally be made responsible for its beginning. It not only serves as an explanation for the Cold War, but can also applied to both inter-human or socio-political constellations. For example, the female student PfB illustrates this at the start of the lesson: The students first discuss their partner work, which is to analyse a caricature. Amongst other things, they find out that Truman and Stalin are depicted in it, and that the two of them are first portrayed together and then separately. Afterwards they start reflecting on the reason for their separation.

02:34 PfB The reason for which they separated? Yes, what does Stalin want? What does, what does the USA want? What does the Soviet Union want?

02:42 PfC Yes, already clearly together, but you know how they before together [...] together fought. (Afterwards) simply because [...] 
02:47 PfB Yes, because there is no reason anymore which they fight for.

02:48 PfC Yes, that is also true again.

02:50 PfB That is, in fact, sometimes also the case with political parties, they fight for something, and after that election it is over because [...] they actually want totally different things. But sure, for this they are $[. .$.

02:57 PfC Yes, yes. This is actually clear.

02:58 PfB Because, it had the advantage for both that - that Hitler was, for example, overthrown.

At the level of the 'specific narrative templates', different narratives are developed in the four classrooms.

\section{The Process: The 'How?' in History Teaching}

Apart from the 'what?', the question as to the 'how?' always arises when teaching history. Here, three factors play a central role, namely the chosen form of teaching, the ensuring of an efficient and, at the same time,

\begin{tabular}{|c|c|c|c|c|}
\hline $\begin{array}{l}\text { «schematic } \\
\text { narrative } \\
\text { template» }\end{array}$ & \multicolumn{4}{|c|}{$\begin{array}{l}\text { The common enemy binds together different parties/interests. } \\
\text { After its defeat, conflicts between former allies come to light openly. } \\
\text { Each party defines its sphere of influence. } \\
\text { Therefore, a separation ensues, but not an open war. }\end{array}$} \\
\hline $\begin{array}{l}\text { «specific } \\
\text { narrative } \\
\text { templates» }\end{array}$ & $\begin{array}{l}\text { Switzerland: } \\
\text { - Nuclear bomb } \\
\text { - Second World } \\
\text { War } \\
\text { - Germany is } \\
\text { dealt with in } \\
\text { sectors }\end{array}$ & $\begin{array}{l}\text { Saxony- } \\
\text { Anhalt: } \\
\text { - Nuclear } \\
\text { bomb } \\
\text { - Second } \\
\text { World War } \\
\text { - Germany is } \\
\text { dealt with in } \\
\text { sectors }\end{array}$ & $\begin{array}{l}\text { Lower Saxony } \\
\text { - Development } \\
\text { of Russia } \\
\text { - Advance of } \\
\text { the Allied } \\
\text { armies } \\
\text { - Cold War } \\
\text { today }\end{array}$ & $\begin{array}{l}\text { Sweden } \\
\text { - Sweden's } \\
\text { position } \\
\text { - Connection } \\
\text { to the } \\
\text { students' } \\
\text { living } \\
\text { environments }\end{array}$ \\
\hline
\end{tabular}

Fig. 18.4 Table of a Common 'Schematic Narrative Template' and Different 'Specific Narrative Templates' in Four Introductory Lessons on the Cold War 
clear classroom management and the form of presentation preferred by the teacher.

\section{The Form of Teaching, Functional Rhythm and Media}

History can be approached and staged in class through four different forms of teaching, which we refer to as 'presenting', 'dialogue-oriented', 'task-based' and 'discovery' history teaching.

Presenting history teaching can be identified when the teachers explain or narrate something. Therefore, the teachers might read out or present texts freely. Of course, here the teacher can enrich the learning experience with further materials, such as pictures or film extracts. Sequences in which the form of teaching remains the same during five minutes are referred to as presentations. In this regard, the observed introductory lessons on the Cold War can be divided into two groups and two lessons fall into each one: Firstly, in the lessons from Sweden and Lower Saxony the presentations take up a lot of time: In Sweden the female teacher narrates the prehistory of the Second World War and the development of the Soviet Union, respectively, and shows a narrative film, which together occupy almost half of the short lesson (min. 15-27). In Lower Saxony, a teacher gives a speech about the Russian/Soviet history of the second half of the nineteenth century up to the Stalin era, which, including interruptions, lasted eleven minutes. Secondly, in both the other lessons there are only short (content-based) presentations which aren't central to the lesson. The presentation explicitly labelled as a 'teacher speech' by the female teacher in the Swiss lesson (min. 55-60) refers to an excursus, a book about the flight of former Nazi functionaries before punishment. The presentation of the teacher in the lesson of Saxony-Anhalt (min. 72-75) does not even last five minutes and takes the form of a mere recapitulation.

Dialogue-oriented history teaching must be distinguished from presenting history teaching. This form can be recognised by the fact that teachers and learners engage in a conversation or mutual exchange in order to deal with a topic. Often teachers ask questions which learners should answer. Teachers and students become aware of things together, explore, 
interpret and develop common value judgements. Dialogue-oriented history teaching is demanding for the learners as well as for the teachers. The four lessons we observed and analysed once again strongly differ from each other: In Lower-Saxony and in Switzerland dialogue-oriented history teaching, in the form of a class discussion, takes up a lot of space. In the lesson from Lower-Saxony the dialogue-oriented teaching lasts 29 minutes (min. 18-47): This approximate half-hour teaching sequence - by far the longest one out of the four lessons - is devoted to the interpretation of a caricature which showed Stalin, Roosevelt and Churchill back to back mounted on horse with two heads (the two halves of which are supposed to trot in the opposite direction). The female teacher gathers the observations of the class and links them with information about the emergence of the conflict between the super powers. Thus, in the course of the lesson the students work out the prehistory of the Cold War through engaging in a dialogue guided and enriched by the teacher. In the lesson from Switzerland the dialogue-oriented teaching lasts twelve minutes (min. 17-29): This teaching sequence also takes place at the beginning of the lesson. From the prior knowledge and the assumptions of individual students, the female teacher delineates the situations in which the victors, the defeated and the different countries in the 'third world' find themselves after the end of war. However, in the lessons in Saxony-Anhalt (min. 32-37) and Sweden (min. 6-14) the sequences of dialogue-oriented teaching are considerably shorter. They are, as it were, pushed to the fringes by the task-based (Saxony-Anhalt) and the presenting teaching (Sweden) methods.

In sequences where the teachers use task-based and discovery history teaching methods, they do not directly control the 'what?' and the 'how?' of the teaching any more. Instead of mediating knowledge, they instead find themselves in the role of the coaches and the learning guides. In taskbased history teaching, the learners are given mostly sources or representations as well as written questions, prompts and assignments. They receive a task and work independently and, guided by their individual assignments, deal with historical documents directly. In discovery history teaching, neither the 'what?' (sources and representations) nor the 'how?' is given straightforwardly to the students. In a self-directed fashion, the students discover things for themselves, explore, interpret, judge and present. Such teaching is usually referred to as 'project teaching'. The task-based history 
teaching takes place most intensively in the lesson in Saxony-Anhalt: In the space of 90 minutes the students are given seven assignments, pausing often to regroup and analyse the processes with which they are working. They, in fact, work independently, but are nevertheless kept on a short leash, with tasks aimed at generating short, closed answers. The lessons in Lower Saxony and in Switzerland include task-based teaching at the beginning, obviously in order to engage the students, and then once again after half (Switzerland) or two thirds (Lower Saxony) of the elapsed time, probably to counter the students' tiredness by introducing something new. The tasks thereby require from students not only the competence to draw information from historical sources and accounts but also the competence to interpret historical events as well as, partly, the ability to position themselves in relation to past experiences. The students must analyse materials, draw connections between them and form their own opinions based on the arguments they (and other students) have made. In the lesson from Sweden task-based teaching is not prominent. All these forms of teaching can be used in different classroom formats, including individual work, partner work, small-group and large-group work, as well as summarising sessions.

Fig 18.5 shows what the profile of the Swiss lesson looks like if for each minute respective codes are assigned. This lesson is characterised by a frequent change of teaching forms. In the first quarter of an hour task-based and presenting history teaching is most prominent. The students are engaged in partner work and watch a film extract. In the second quarter of an hour dialogue-oriented teaching follows. In the third quarter of an hour, task-based teaching predominates, and in the last quarter of an hour presentations occur again, taking the form of explanations by the teacher.

In order to compare several lessons, profiles which only present the three teaching forms and in which we can assign a code every five minutes are most useful. Table 18.1, for example, allows us to compare the four introductory lessons. At first glance, the structural similarity of the lessons from Switzerland and Lower Saxony becomes evident. These are double lessons with a central focus based in a long class discussion. Presenting and task-based teaching lead up to it and away from this focus, respectively. Concerning the Swiss lesson, these forms of teaching are divided into shorter steps than in the Lower-Saxony lesson.

The lesson in Saxony-Anhalt is almost entirely built up on task-based teaching. The tasks are evaluated in a group session before the next task is 


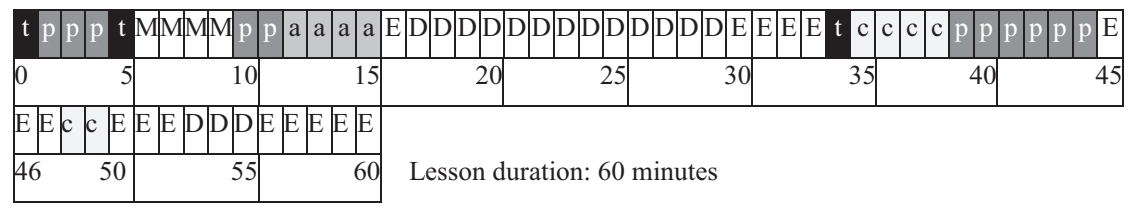

Task basis

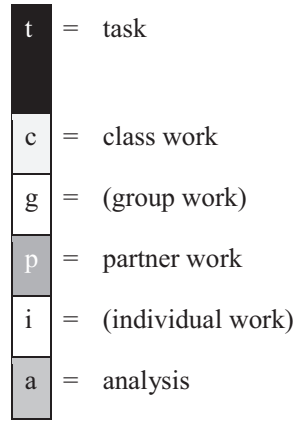

Presentation

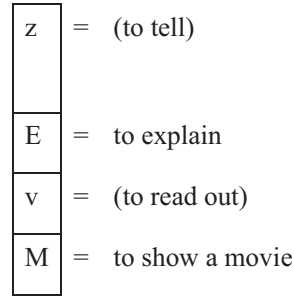

Class discussion

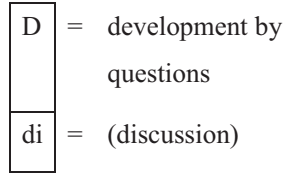

Residual category \begin{tabular}{|l|l}
\hline $\mathrm{S}$ & $=\quad$ (subject-related) \\
$\mathrm{N}$ & $=$ (not subject-related)
\end{tabular}

Fig. 18.5 Table of Presentation of the Form of Teaching: Profile of the Swiss Lesson in Coding per Minutes (in brackets: teaching forms not occurring here)

Saxony-Anhalt

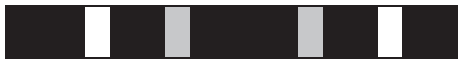

Lower Saxony

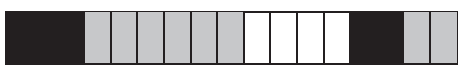

Sweden

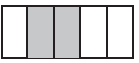

Switzerland

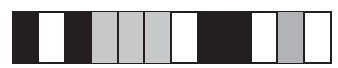

Fig. 18.6 Table of Presentation of the Form of Teaching in Five Minute Coding: 'Task-based' (black), 'Presenting' (white) and 'Dialogue-oriented' (grey) Forms 
Table 18.1 Table of the Teaching Forms of the Four Analysed Lessons in Comparison

\begin{tabular}{|c|c|c|c|c|c|}
\hline & & $\begin{array}{l}\text { Saxony- } \\
\text { Anhalt }\end{array}$ & $\begin{array}{l}\text { Lower } \\
\text { Saxony }\end{array}$ & Sweden & Switzerland \\
\hline $1 \mathrm{a}$ & Share of task-based teaching & $78 \%$ & $37 \%$ & $0 \%$ & $40 \%$ \\
\hline $1 \mathrm{~b}$ & Share of presenting teaching & $6 \%$ & $17 \%$ & $65 \%$ & $33 \%$ \\
\hline \multirow[t]{2}{*}{$1 c$} & $\begin{array}{l}\text { Share of dialogue-oriented } \\
\text { teaching }\end{array}$ & $16 \%$ & $46 \%$ & $35 \%$ & $27 \%$ \\
\hline & In total & $100 \%$ & $100 \%$ & $100 \%$ & $100 \%$ \\
\hline $2 a$ & $\begin{array}{l}\text { Average duration of a } \\
\text { task-based, presenting and a } \\
\text { class-discussion sequence }\end{array}$ & $7 \mathrm{~min}$. & $12 \mathrm{~min}$. & $4 \mathrm{~min}$. & $5 \mathrm{~min}$. \\
\hline $2 \mathrm{~b}$ & Standard deviation from $2 \mathrm{a}$ & 5.5 & 9.4 & 2.4 & 3.6 \\
\hline $2 c$ & Median value analog to $2 a$ & $6 \mathrm{~min}$. & $12 \mathrm{~min}$. & $4 \mathrm{~min}$. & $4 \mathrm{~min}$. \\
\hline
\end{tabular}

introduced in class teaching. This rhythm is strictly adhered to over the length of a double lesson.

In the short lesson in Sweden task-based teaching is, however, missing. The female teacher provides an introduction into the topic of the Cold War through an explanation. The class discussion is thus given a frame, and it obviously serves to involve the students in the discussion. This finding is supported by the more detailed quantitative evaluation.

The four lessons differ as regards teaching forms, but also concerning the staged learning processes. At all times the teachers obviously had found their own functional rhythms to best teach their students. It is important to consider how a complete learning process is correctly built up. In the Swiss lesson, for example, the female teacher tries to spark the students' curiosity and to engage them at the beginning of the lesson. Afterwards the students repeat the things they have learned, linking these with what they have learnt previously. After that the students work on learning tasks which serve to deepen their new knowledge, and at the end the teacher first provides a thematic overview once again, so that the students' new knowledge is reinforced, and then gives a summary on other interesting topics which will be dealt with in future lessons.

Such a learning process ensures a wide variety of stimulating, engaging and appropriate learning opportunities. If one compares the four lessons 


\begin{tabular}{|c|c|c|c|c|c|}
\hline & \multirow[b]{2}{*}{-} & & & \\
\hline & & & 0 & + & ++ \\
\hline \multirow{5}{*}{$\begin{array}{l}\text { 8. Ensuring } \\
\text { stimulating, } \\
\text { engaging and } \\
\text { appropriate } \\
\text { learning } \\
\text { opportunities }\end{array}$} & $\begin{array}{l}\text { a. The teacher adjusts the learning tasks } \\
\text { according to the students' knowledge. } \\
\text { He/she makes sure that the majority of } \\
\text { the students can master them. }\end{array}$ & & 00 & $\diamond X$ & \\
\hline & $\begin{array}{l}\text { b. The teacher adjusts the complexity of } \\
\text { the topic according to their students' } \\
\text { stage of development. }\end{array}$ & & $\mathbf{O}$ & 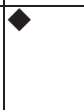 & OX \\
\hline & $\begin{array}{l}\text { c. The teacher chooses student activities } \\
\text { which are well-suited for achieving the } \\
\text { objectives and ensure efficient learning. }\end{array}$ & $\bullet$ & $\Delta O$ & & $X$ \\
\hline & $\begin{array}{l}\text { d. The teacher makes sure that all the } \\
\text { learners are cognitively engaged. }\end{array}$ & & 0 & $\triangle O X$ & \\
\hline & $\begin{array}{l}\text { e. The teacher makes sure that the } \\
\text { students' new knowledge will be long } \\
\text { term. He/she links new content with } \\
\text { already existing knowledge. }\end{array}$ & - & $\downarrow$ & X & $\mathbf{O}$ \\
\hline
\end{tabular}

Key: -: not true, 0 : just true, + : very true, ++ : pronouncedly true

Fig. 18.7 Table Ensuring Stimulating, Engaging and Appropriate Learning

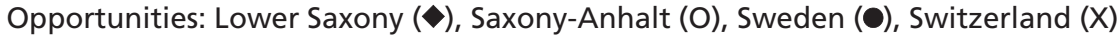

from the perspective of these criteria, the lesson from Switzerland obtains the best rating.

Apart from the form of teaching and the functional rhythm, the media used in each lesson allows us to see the inclusion of the 'how?' of history teaching to a considerable extent. Besides the traditional media such as text sources, pictures or maps, various other types of other media, for example caricatures, comics, films or hypermedia, are also used in these lessons. In the Swiss lesson the variety of media used is stark compared to the other three lessons. The lesson starts with the interpretation of a projected caricature, which was also handed out on paper (min. 1) and its message is compared with a film on YouTube (min. 5-9). The second sequence relies on a partly prepared, partly dialogue-oriented blackboard text in tabular form (min. 15). The third sequence is based on two text sources in the textbook, which in partner work are opposed and compared to each other (min. 35). Afterwards (min. 45), the female teacher presents a chronological overview of the period in the form of a PowerPoint 
presentation, draws the division of Germany onto a map projected onto a screen (min. 47) and shows her students a book, the content of which she briefly summarises (min. 56).

\section{Classroom Management, Classroom Climate and Clarity}

Classroom management and the use of time in the class, the classroom climate as well as clarity and structure of the teacher's explanation also play an important role when designing teaching lessons (Gautschi 2012, 81-88). In order to manage a class efficiently and to use the teaching time well, it is important for teachers to set clear rules and make sure they are followed. Here rituals which support learning are useful. Special attention should be paid to the start and the end of the teaching: Are the teaching forms used here appropriate to the situation? Do they support the management of the class? Teachers can ensure that they use as much available teaching time as possible if they keep transitions streamlined. Good time management also leads to successful learning. Figure 18.8 shows the evaluation of the four lessons in this area. Here again, the Swiss lesson comes out best.

Gerhard Schneider outlines four different ways teachers might start a lesson: They can arouse interest in the topic (A), activate the prior knowledge and the prior experiences of their students (B), problematise the topic (C) or calm down the class (D) $(2008,26)$. In the lessons we analysed, types A, B and C occur. Type A stops the teacher from giving merely

\begin{tabular}{|l|l|l|l|l|}
\cline { 2 - 5 } \multicolumn{1}{l|}{} & - & 0 & + & ++ \\
\hline $\begin{array}{l}\text { 9. Ensuring efficient classroom management and use of } \\
\text { time }\end{array}$ & & $\diamond$ & $\mathbf{X}$ & $\mathbf{O}$ \\
\hline 10. Fostering a supportive classroom climate & & $\mathbf{O}$ & $\diamond \mathbf{O X}$ & \\
\hline 11. Ensuring appropriate clarity and structure & & $\mathbf{O}$ & $\bullet \mathbf{X}$ & \\
\hline
\end{tabular}

Key: -: not true, 0 : just true, + : very true, ++ : pronouncedly true

Fig. 18.8 Table Ensuring a Classroom Environment Conductive to Learning: Lower Saxony $(\diamond)$, Saxony-Anhalt $(O)$, Sweden $(\bullet)$, Switzerland (X) 
an explanatory introduction and instead suggests that the teacher confront the class with a source, despite their lack of knowledge. The gaps in the students' knowledge mean they are more engaged, as they want to fill these gaps. In contrast, type B possibly activates existing prior knowledge but it also draws on the students' assumptions, thus falling back on ideas from the sphere of historical culture. Type B represents a 'sound of the bell' type of teaching, enriched with content: The lesson starts, the class engage with and focus on the topic.

Table 18.2 Table of Beginning a Lesson, according to Gerhard Schneider (2008)

\begin{tabular}{|c|c|c|c|c|}
\hline & Saxony-Anhalt & Lower Saxony & Sweden & Switzerland \\
\hline Type & $A$ & $B$ & D & A \\
\hline Characteristic & $\begin{array}{l}\text { Interpreting } \\
\text { a caricature } \\
\text { on the } \\
\text { emergence } \\
\text { of the } \\
\text { bipolarity of } \\
\text { the Cold War } \\
\text { in individual } \\
\text { work }\end{array}$ & $\begin{array}{l}\text { Brainstorming } \\
\text { on } \\
\text { assumptions } \\
\text { and } \\
\text { associations } \\
\text { about the } \\
\text { Cold War in } \\
\text { group work }\end{array}$ & $\begin{array}{l}\text { Organisation of } \\
\text { the lesson } \\
\text { setting, } \\
\text { catching the } \\
\text { attention of } \\
\text { the students, } \\
\text { narrative } \\
\text { recapitulation }\end{array}$ & $\begin{array}{l}\text { Interpreting a } \\
\text { caricature on } \\
\text { the } \\
\text { emergence } \\
\text { of the } \\
\text { bipolarity of } \\
\text { the Cold War } \\
\text { in individual } \\
\text { work }\end{array}$ \\
\hline Duration & $\begin{array}{l}16 \text { min., with } \\
\text { two } \\
\text { assignments } \\
\text { and } \\
\text { evaluation }\end{array}$ & $\begin{array}{l}17 \text { min., } \\
\text { thereof } \\
9 \text { min. of } \\
\text { evaluation }\end{array}$ & $\begin{array}{l}2 \text { min., without } \\
\text { student } \\
\text { activity }\end{array}$ & $\begin{array}{l}4 \text { min., } \\
\text { without } \\
\text { immediate } \\
\text { evaluation }\end{array}$ \\
\hline $\begin{array}{l}\text { Student } \\
\text { activity }\end{array}$ & $\begin{array}{l}\text { Individual } \\
\text { work, } \\
\text { written } \\
\text { form, } \\
\text { various, } \\
\text { mostly } \\
\text { wait-and-see }\end{array}$ & $\begin{array}{l}\text { Group work, } \\
\text { written } \\
\text { form, } \\
\text { different as } \\
\text { regards } \\
\text { results }\end{array}$ & - & $\begin{array}{l}\text { Individual } \\
\text { work, } \\
\text { opportunity } \\
\text { for written } \\
\text { form, } \\
\text { assumingly } \\
\text { concentrated }\end{array}$ \\
\hline $\begin{array}{l}\text { Link to the } \\
\text { lesson }\end{array}$ & Coherent & Coherent & Coherent & Coherent \\
\hline $\begin{array}{l}\text { Referred to } \\
\text { again in the } \\
\text { lesson }\end{array}$ & $\begin{array}{l}\text { In the } \\
\text { summary }\end{array}$ & Not any more & $\begin{array}{l}\text { Motif of the } \\
\text { memory of the } \\
\text { parent/teacher } \\
\text { generation is } \\
\text { taken up one } \\
\text { single time }\end{array}$ & $\begin{array}{l}\text { At the } \\
\text { beginning of } \\
\text { the dialogue- } \\
\text { oriented part }\end{array}$ \\
\hline
\end{tabular}


The teachers in Sweden and Lower Saxony introduce the topic and the term 'Cold War' when they start the lesson, whereas the teachers in the two other lessons, with the type A method of starting a lesson, do not (Switzerland, min. 0: 'I still do not exactly tell you what the [topic] is'). Thus, the teachers seem to want to avoid pre-empting any interpretation of the caricature presented and used as an introduction.

\section{Presentation Concepts}

According to Michele Barricelli, we can distinguish six presentation concepts which, on the one hand, constitute a basic pattern of historiography, but, on the other, are also applicable to teaching (2012, 202-223; see also Table 18.3).

Table 18.3 Table of Presentation Concepts according to Barricelli

\begin{tabular}{|c|c|c|}
\hline Presentation concept & Principle & Characteristic(s) \\
\hline $\begin{array}{l}\text { Genetic- } \\
\text { chronological } \\
\text { narrative }\end{array}$ & $\begin{array}{l}\text { Presenting and explaining } \\
\text { history over the course of time, } \\
\text { arbitrary beginnings and ends }\end{array}$ & $\begin{array}{l}\text { Linking additive, } \\
\text { temporal, adversative, } \\
\text { conditional }\end{array}$ \\
\hline Longitudinal cut & $\begin{array}{l}\text { Concentration of the genetic } \\
\text { narratives on one single topic } \\
\text { relevant to the present }\end{array}$ & $\begin{array}{l}\text { No historical but } \\
\text { thematic linking, } \\
\text { marked gaps in } \\
\text { continuity }\end{array}$ \\
\hline Cross section & $\begin{array}{l}\text { Concentration on a time period } \\
\text { in one area including many } \\
\text { historical areas (society, } \\
\text { politics, culture, economy) }\end{array}$ & Linking of contexts \\
\hline Case analysis & $\begin{array}{l}\text { Reduction of complexity of } \\
\text { information; on the other } \\
\text { hand, focus on opinion and } \\
\text { decision making on the part of } \\
\text { the students }\end{array}$ & $\begin{array}{l}\text { Reference to a problem } \\
\text { relevant also today; } \\
\text { discovery-exploratory } \\
\text { learning }\end{array}$ \\
\hline $\begin{array}{l}\text { Constellation } \\
\text { analysis }\end{array}$ & $\begin{array}{l}\text { Presenting and working out } \\
\text { models on connections within } \\
\text { a historical constellation }\end{array}$ & $\begin{array}{l}\text { Visualisation, forming } \\
\text { models }\end{array}$ \\
\hline $\begin{array}{l}\text { Individualising and } \\
\text { biographical } \\
\text { procedure, } \\
\text { respectively }\end{array}$ & $\begin{array}{l}\text { Focus on the human being in } \\
\text { history, in the sense of } \\
\text { personification, often in the } \\
\text { form of collective biographies }\end{array}$ & Vividness, concreteness \\
\hline
\end{tabular}


An analysis of the lessons as regards the presentation concepts again reveals a striking similarity between them: All four teachers put into practice a constellation analysis (Fig. 18.9). The political, economic and (partly) ideological constellation of the Cold War is brought into focus. In all cases, both the camps are opposed to each other in verbal as well as visual terms and compared with one another with respect to economic order, the function of the state or the weighting of the individual. A chronological-genetic derivation of this constellation is touched upon in three of the four lessons but does not in any of the cases contribute to the explanation of the emergence of the Cold War. Events mentioned, such as the nuclear bomb, the

\begin{tabular}{|c|c|c|}
\hline Saxony-Anhalt & \begin{tabular}{|l|r|} 
& \\
& \\
West-East conflict \\
& \\
West & East \\
\end{tabular} & $\begin{array}{l}\square \\
\text { Berlin Wall / confron- } \\
\text { tation } 1961\end{array}$ \\
\hline $\begin{array}{l}\text { Niedersachsen } \\
\text { Advance 1944/45 }\end{array}$ & \multirow{2}{*}{\begin{tabular}{|l|r|}
\multicolumn{2}{|c|}{ West-East conflict } \\
& \\
West & East \\
\end{tabular}} & \multirow[b]{2}{*}{$\begin{array}{c}\text { (Ukraine conflict) } \\
\bigcirc\end{array}$} \\
\hline $\begin{array}{l}\text { History of Russia } \\
\text { and the Soviet Union }\end{array}$ & & \\
\hline
\end{tabular}

\section{Sweden}

$\square$ The great Northern War 1700-1721

Expansion of Russia and the USA

Second World

War

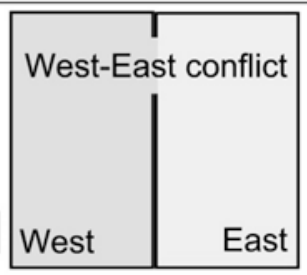

\section{Switzerland}

Second World

War

Use of nuclear arms

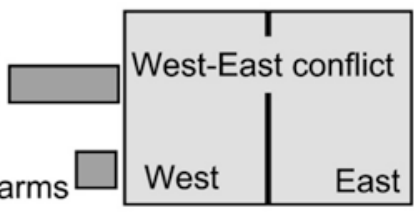

East

Germany dealt with in sectors

time

Fig. 18.9 Table of Visualisation of the Presentation Concepts according to Barricelli on a Timeline in the Four Lessons 
Second World War, the Great Northern War or the Berlin Wall, are there mainly to reinforce the students' knowledge and thus serve the purpose of illustration. The illustration makes up for the weakness of a constellation analysis which as an abstracting model hardly allows a teacher to draw on the students' own daily lives. On the other hand, it allows for an overview and proffers easy-to-learn knowledge by reducing complexity.

At the same time, the constellation analysis, which allows the students to see an overview of the issues and acquire knowledge easily, requires a great deal of intellectual preparatory work from the part of the teacher. The teacher must first understand these constellations, so must fall back on both specialised literature and their own knowledge of the topic.

\section{For the Students' Use - the 'What for?' of Teaching History}

By dealing with history, individuals can answer crucial questions regarding their existence: How have I become the person I am today? How have we become what we are? What has changed, in what way and why? How do I arrive at my judgement on history? What shall I do? What do I want to do? In helping tackle these questions, history teaching contributes to building individual and social identity by providing the basic narrative of a society (Gautschi, Furrer and Sommer 2014, 9-12). At the same time, history teaching also enables students to think in historical terms. They are able to acquire the knowledge and abilities to build opinions and attitudes.

\section{Historical Learning}

For teachers and learners historical learning involves four different, but interwoven, mental processes (become aware of things, explore, interpret, orient oneself) which allow for historical narration. In Fig. 18.10, these mental operations are illustrated in a structure and process model: The processes are represented as arrows, the products as squares.

Historical learning takes place when an individual, imbedded in society and thus in change over time, approaches a certain period of history. 


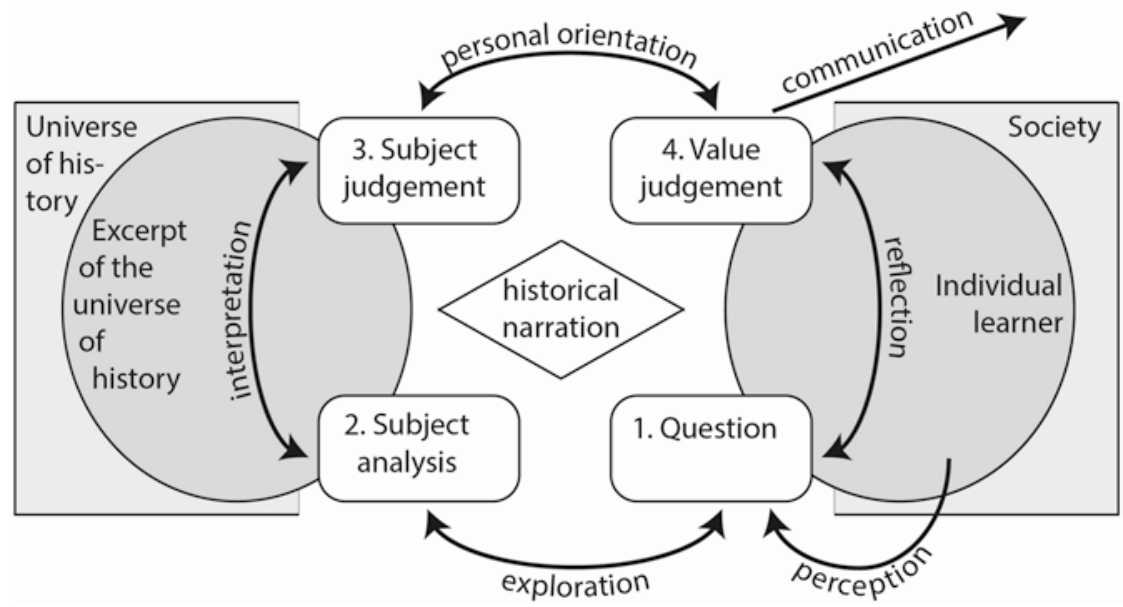

Fig. 18.10 Structure and Process Model of Historical Learning

Historical learning starts when learners specifically focus their attention on a section of the past and become aware of facts from this period (sources, representations) or when they encounter people who represent or narrate history. The learners draw information from their findings, reconstructing narratives of the period from historical testimonies. They work out a factual analysis' (Jeismann 2000, 63) in which 'factual findings' (Weymar $1970,202)$ are presented by them. In a next step they interpret these factual findings, establish relations to other historical testimonies and, in doing so, place their findings in a larger context of causes and effects. Thus, they arrive at a 'historical factual judgement' (Jeismann 2000, 64). Then the learners can establish a relation between this historical factual judgement and their own personal opinion. They arrive at a bistorical value judgement' (Ibid., 64) with respect to present or future, individual or social situations and problem areas. The value judgement will eventually be compatible with the currently valid and accepted moral values of 
the present society in which the individual lives, and, therefore, it needs to be examined on the basis of this. This happens within the 'objectivityforming discourse' in which the 'normative validity' is established by means of 'reflection and justification' of one's own viewpoint (Rüsen 1997). Therefore, the value judgement becomes the starting point for dialogue with others, which in itself is again the cause of further questions about history, the past, the present or the future. The value judgement might furthermore trigger an individual to act.

This process might also happen in reverse: The learners question a value judgement on the basis of the underlying factual judgement and in turn question that factual judgement on the basis of the underlying factual analyses. Both processes, both of de- and reconstruction, are emphasised by the authors of the working group 'FUER Geschichtsbewusstsein' (FOR Historical Awareness) (Schreiber et al. 2007, 21).

These mental processes between questions, factual analyses, factual judgements and value judgements come up in 'historical narration'(Rüsen $2008,75)$. Therefore, 'historical narration' is represented as a basic competence in Fig. 18.10 (centre).

\section{The Role of the Learner in History Teaching}

In what way is such historical learning then fostered in the four lessons? Overall, it must be said that in the observed lessons little historical learning can, in fact, be observed. The lessons are knowledge-oriented, especially the ones from Switzerland and from Saxony-Anhalt.

It comes as no surprise that students hardly have the opportunity to become aware of things by themselves, as Criterion 11 in Fig. 18.11 shows. If teachers include selected topics with a constellation analysis, there is hardly any space for the learners' own awareness to develop.

What is more successful in the observed lessons is the ability of the students to interpret (Criterion 13). Because interpreting (Criterion 15) is closely linked to acquiring knowledge, this assessment is not surprising.

In the observed lessons the students hardly have a chance to orient themselves. Only very few value judgements are openly made. This might also be a characteristic of introductory lessons. Possibly the students 


\begin{tabular}{|l|l|l|l|l|}
\hline $\begin{array}{l}\text { 11. Awareness of historical testimonies and of changes } \\
\text { over time }\end{array}$ & $\mathbf{O X}$ & $\mathbf{O}$ & & \\
\hline $\begin{array}{l}\text { 12. Exploring, examining and presenting of historical } \\
\text { factual analyses (competence to draw information from } \\
\text { historical sources and accounts) }\end{array}$ & & $\checkmark \mathbf{O O}$ & & \\
\hline $\begin{array}{l}\text { 13. Interpretation (analysis and interpretation of history } \\
\text { (competence to interpret historical events) }\end{array}$ & & $\mathbf{O O}$ & $\boldsymbol{\nabla X}$ & \\
\hline $\begin{array}{l}\text { 14. Orientation: Meaning formation via past experiences } \\
\text { and value judgement examination on the basis of past } \\
\text { experiences (competence to position oneself in relation } \\
\text { to past experiences) }\end{array}$ & $\mathbf{O}$ & $\mathbf{O X}$ & & \\
\hline $\begin{array}{l}\text { 15. Acquiring and reproducing knowledge about past } \\
\text { events and the understanding of history }\end{array}$ & & $\checkmark \mathbf{O X}$ & $\mathbf{O X}$ & \\
\hline
\end{tabular}

Key: -: not true, 0: just true, +: very true, ++ : pronouncedly true

Fig. 18.11 Table of Evaluation of the Use of History Teaching; Lower Saxony $(\bullet)$, Saxony-Anhalt (O), Sweden (O), Switzerland (X)

might have developed only very few factual analyses and factual judgements as yet and are therefore not confident enough to make any value judgements, which, in fact, can be considered rather positive.

\section{Conclusion}

\section{Overall Evaluation of the Lessons}

Fig. 18.12 summarises the results of applying the above findings to the four introductory lessons. Two aspects are particularly striking: First of all, differences mainly emerge in the process of history teaching, in criteria which are independent of both the topic being taught and general didactic expectations. Secondly, we can see that, overall, only few similarities exist between the lessons observed, despite the fact that in all four lessons the same 'schematic narrative template' and the same presentation rationale was used.

Generally, we can ascertain that (a) in all 4 lessons a reference to the present was made, without, however, drawing upon the students' own 


\begin{tabular}{|c|c|c|c|c|c|}
\hline & & - & $O$ & + & ++ \\
\hline & 1. Significant topic & & & $\circ \times$ & \\
\hline & $\begin{array}{l}\text { 2. Thematisation of changes over } \\
\text { time and development contexts }\end{array}$ & & $\mathbf{O O}$ & $\Delta \mathrm{X}$ & \\
\hline 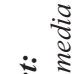 & $\begin{array}{l}\text { 3. Thematisation of human action } \\
\text { in social practice }\end{array}$ & & $>0 X$ & & \\
\hline 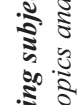 & $\begin{array}{l}\text { 4. Exemplary and target-group- } \\
\text { adjusted representations of } \\
\text { history }\end{array}$ & $\mathbf{O}$ & $>$ & $\boldsymbol{O X}$ & \\
\hline 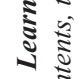 & $\begin{array}{l}\text { 5. Validity, multi-perspectivity and } \\
\text { controversy }\end{array}$ & & O & $\mathbf{O}$ & $\diamond \mathrm{X}$ \\
\hline i & 6. Reference to the present & & & $\diamond \odot \times O$ & \\
\hline & $\begin{array}{l}\text { 7. Reference to the students' living } \\
\text { environment }\end{array}$ & & $>00 \mathrm{X}$ & & \\
\hline & 8. Methods of historical knowledge & $\mathbf{O}$ & $\Delta \mathrm{XO}$ & & \\
\hline 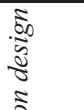 & $\begin{array}{l}\text { 9. Ensuring of an efficient } \\
\text { classroom management and use } \\
\text { of time }\end{array}$ & & $\odot \bullet$ & $\mathbf{X}$ & $\mathbf{O}$ \\
\hline 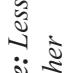 & $\begin{array}{l}\text { 10. Fostering a supportive classroom } \\
\text { climate }\end{array}$ & & $\mathbf{O}$ & 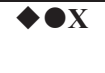 & \\
\hline 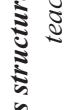 & $\begin{array}{l}\text { 11. Ensuring of stimulating, } \\
\text { engaging and appropriate } \\
\text { learning opportunities }\end{array}$ & & 00 & $\Delta \mathbf{X}$ & \\
\hline ఏँ & $\begin{array}{l}\text { 12. Ensuring appropriate clarity and } \\
\text { structure }\end{array}$ & & $\mathbf{O O}$ & $\Delta \mathbf{X}$ & \\
\hline 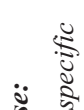 & $\begin{array}{l}\text { 13. Awareness of historical } \\
\text { testimonies and ofchanges over } \\
\text { time }\end{array}$ & $\mathbf{O X}$ & $\bullet \bullet$ & & \\
\hline 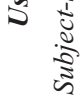 & $\begin{array}{l}\text { 14. Exploring, examining and } \\
\text { presenting of historical factual } \\
\text { analyses }\end{array}$ & & $0 x>0$ & & \\
\hline & $\begin{array}{l}\text { 15. Interpretation (analysis and } \\
\text { interpretation) of history }\end{array}$ & & $\mathbf{O}$ & $\diamond \mathbf{X}$ & \\
\hline & $\begin{array}{l}\text { 16. Orientation: Meaning formation } \\
\text { via past experiences and value } \\
\text { judgement examination on the } \\
\text { basis of past experiences }\end{array}$ & $\mathbf{O}$ & 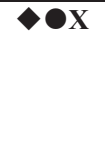 & & \\
\hline & $\begin{array}{l}\text { 17. Acquiring and reproducing of } \\
\text { knowledge about past events and } \\
\text { understanding of history }\end{array}$ & & 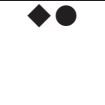 & $\mathbf{O X}$ & \\
\hline
\end{tabular}

Key: -: not true, 0 : just true, + : very true, ++ : pronouncedly true

Fig. 18.12 Table of Overall Evaluation of the Lessons after Points; Lower Saxony $(\diamond)$, Saxony-Anhalt (O), Sweden (O), Switzerland (X) 
experiences, (b) in 3 of 4 lessons, significant topics were taught; (c) 3 of 4 lessons were factually correct, multi-perspectival and controversial; (d) 3 out of 4 lessons featured engaging and appropriate learning opportunities; d) hardly any attention was given to human action in societal practice, and finally (e) the students had only few opportunities for their own perceptions, to draw information from historical sources, or for their own orientation. We therefore conclude that little historical learning occurred in the lessons observed.

\section{Students at the Focus!}

What was the reason for the pronounced lack of historical learning in these lessons? One explanation might be that, in introductory lessons in particular, teachers often think from the angle of the topic per se. This may be reinforced by particularly demanding analysis that was selected in order to present that subject matter.

When it comes to selecting a presentation concept, there are other opportunities which would allow teachers to reference both the present and the daily lives of their students. We shall briefly outline 4 alternatives here. Firstly, there is the longitudinal cut, in which students would be taught the history of the Ukraine, for instance, from the brief period of independence (1917-1920), through the Second World War, the integration into the Eastern bloc, the independence in 1991 until the annexation of Crimea and the separatism of Eastern Ukraine. Secondly, teachers may opt for a cross-section, which would examine the situation in 1945 and the lives of those in war-ravaged countries as well as those spared from war, further allowing students to look at society, economy and culture. Thirdy, a case study would present a specific scenario, such as the abduction of the lawyer Dr. Walter Linse from West Berlin into the East sector on $8^{\text {th }}$ July 1952, as well as the mechanics of the Cold War at the level of the population, the governments in East and West Berlin and even in the USA and the Soviet Union. All of this can be demonstrated vividly, rendering clear to students the impact of the Cold War on individuals. Fourth, teachers might select an individualising procedure, cov- 
ering, for instance, the history of displaced people from East Prussia in 1945 and their later integration in the FRG.

In order to ensure that historical learning does take place, even in introductory lessons, teachers must stress the relevance of the topic to the students' own living environments. The learners' question when confronted with the Cold War, 'and what has this got to do with me?' (cf. Thurn $1993^{2}$ ), can be answered in different ways; however, it is crucial that students recognise and understand 'what reflecting on past events has got to do with their present and future' (Bergmann 2004, 91-92). When learners apply historical learning as their method, they have to first know what historical learning is. This idea has as yet not been given enough attention. However, the standard history textbooks all feature explanations in their preliminary pages as to what history is, also providing definitions of terms such as 'sources', 'representations', 'chronology' or 'archaeology'. Yet what exactly historical teaching is and wherein historical thinking differs, for example, from mathematical thinking is not explained (cf. Fuchs et al. 2016, 4-5) ${ }^{3}$.

It is evident that students learn best if they know the reasons why they are studying certain topics and why they are being taught via certain methods (Cf. Beck et al. 1995; Messner 1998). Successful students begin to learn with the prior knowledge of how they will be taught. They observe and reflect upon how they themselves learn and control their own learning efficiently. In contrast to the less successful students, the successful ones learn with awareness (Messner 1998). It is certainly not a new discovery that students themselves must reflect upon their own ways of learning or that history teaching should relate to the students' own living environments and offer them the opportunity to be a part of guiding their own learning. The popularity of student-oriented history teaching has increased in the last few years, particularly in regards to competence orientation. Obviously, however, such an approach to teaching history does not occur on a day-to-day basis. Our analysis of the four introductory lessons suggests that subject- and science-driven approaches still predominate when it comes to teaching history (Rohlfes 1986, 177). Those involved in teaching history must ensure that in the future students come even further into the focus! 


\section{Notes}

1. The evaluation of the lessons was carried out by Peter Gautschi and Hans Utz together with research assistant Antje Suter and student assistant Jasmine Steger, using the criteria on a four-point scale. The four evaluations were averaged and rounded. No examination of the inter-rater reliability was conducted due to the explorative character of the procedure.

2. Cf. Susanne Thurn: '[...] und was hat das mitmirzu tun?': Geschichtsdidaktische Positionen (Pfaffenweiler: Centaurus). She presents the objectives of her own teaching in regards to history education and writes: 'I would like that my students [...] when having pressing - pressing them and pressing our society - problems ask inquiring historical questions because they have learnt that the historical dealing with intentions, conditions restricting action and hindrances of all sorts might be useful for them' (Thurn 1993, 255).

3. An exception is the school history textbook Zeitreise, which at the beginning of each volume, on the basis of a monument, defines historical learning (Fuchs et al. 2016).

\section{Bibliography}

\section{Textbooks Cited:}

Fuchs, Karin, Peter Gautschi and Hans Utz. 2016. Zeitreise 1. Das Lehrwerk für historisches Lernen im Fachbereich 'Räume, Zeiten, Gesellschaften'. Edition for Switzerland. Baar: Klett und Balmer.

\section{Further References:}

Barricelli, Michele. 2012. 'Darstellungskonzepte von Geschichte im Unterricht'. In Handbuch Praxis des Geschichtsunterrichts. Volume 2, ed. by Michele Barricelli and Martin Lücke, 202-223. Schwalbach/Ts.: Wochenschau Verlag.

Beck, Erwin, Guldimann, Titus, Zutavern, Michael. 1995. 'Eigenständig lernende Schülerinnen und Schüler'. In Eigenständig lernen, ed. by Erwin Beck, Titus Guldimann and Michael Zutavern, 15-58. St. Gallen: UVK, Fachverlag für Wissenschaft und Studium. 
Bergmann, Klaus. 2004. 'Gegenwarts- und Zukunftsbezug'. In Handbuch Methoden im Geschichtsunterricht, ed. by Ulrich Mayer, Hans-Jürgen Pandel and Gerhard Schneider, 91-112. Schwalbach/Ts.: Wochenschau Verlag.

Furrer, Markus, Gautschi, Peter. 2017. 'Memory Cultures and History Education. Introduction'. In Remembering and Recounting the Cold War, ed. by Markus Furrer and Peter Gautschi, 11-26. Schwalbach/Ts.: Wochenschau Verlag.

Gautschi, Peter. 2012. Guter Geschichtsunterricht, Grundlagen, Erkenntnisse, Hinweise. 2nd Edition. Schwalbach/Ts.: Wochenschau Verlag.

Gautschi, Peter, Furrer, Markus, Sommer Häller, Barbara. 2014. 'Umgang mit Geschichte und Erinnerung in Schule und Hochschule'. In Der Beitrag von Schulen und Hochschulen zu Erinnerungskulturen, ed. by Peter Gautschi and Barbara Sommer Häller, 7-24. Schwalbach/Ts.: Wochenschau Verlag.

Gautschi, Peter, Fink, Nadine. 2016. 'Lehrplanlyrik und Unterrichtsalltag in der Schweiz: Einblicke in fächerverbindendes historisches Lernen in der deutschund französischsprachigen Schweiz'. In Geschichte im interdisziplinären Diskurs. Grenzziehungen - Grenzüberschreitungen - Grenzverschiebungen, ed. by Michael Sauer, Charlotte Bühl-Cramer, Anke John, Astrid Schwabe, Alfons Kenkmann and Christian Kuchler. 131-150. Göttingen: V\&R Uni Press.

Jeismann, Karl-Ernst. 2000. Geschichte und Bildung: Beiträge zur Geschichtsdidaktik und zur Historischen Bildungsforschung. Paderborn: Ferdinand Schöningh Verlag.

Mayer, Ulrich. 2005. 'Qualitätsmerkmale historischer Bildung. Geschichtsdidaktische Kategorien als Kriterien zur Bestimmung und Sicherung der fachdidaktischen Qualität des historischen Lernens'. In Zeitgeschichte und historische Bildung. Festschrift für Dietfrid Krause-Vilmar, ed. by: Wilfried Hansmann and Timo Hoyer. 223-243. Kassel: Jenior.

Helmut Messner. 1998. 'Die kompetente Lernerin, der kompetente Lerner'. Forum Schule Heute 12 (4). 3-6.

Pandel, Hans-Jürgen. 2006. Quelleninterpretation. Die schriftliche Quelle im Geschichtsunterricht 3rd Edition. Schwalbach/Ts: Wochenschau Verlag. Rohlfes, Joachim. 1986. Geschichte und ihre Didaktik. Göttingen: Vandenhoeck \& Ruprecht.

Rüsen, Jörn. 1997. 'Objektivität'. In Handbuch der Geschichtsdidaktik 5th Edition, Revised Edition, ed. by Klaus Bergmann, Klaus Fröhlich and Annette Kuhn, 160-163. Seelze-Velber, Kallmeyer.

Rüsen, Jörn. 2008. Historisches Lernen. Grundlagen und Paradigmen Volume 2, Revised and Extended Edition. Schwalbach/Ts.: Wochenschau Verlag. 
Schneider, Gerhard. 2008. Gelungene Einstiege. Voraussetzung für erfolgreiche Geschichtsstunden 5th Edition. Schwalbach/Ts.: Wochenschau Verlag. Schreiber, Waltraud, Körber, Andreas, von Borries, Bodo. 2007. 'Historisches Denken. Ein Kompetenz-Strukturmodell'. In Kompetenzen historischen Denkens. Ein Strukturmodellals Beitragzur Kompetenzorientierung in der Geschichtsdidaktik, ed. by Andreas Körber / Waltraud Schreiber and Alexander Schöner. 17-53. Neuried: Ars Una [Kompetenzen: Grundlagen - Entwicklung - Förderung]. Thurn, Susanne. 1993. '[...] und was hat das mit mir zu tun?': Geschichtsdidaktische Positionen. Pfaffenweiler: Centaurus.

Wehler, Hans-Ulrich. 2006. Deutsche Gesellschaftsgeschichte. Volume 1, 4th Edition. München: C.H. Beck.

Weymar, Ernst. 1970. 'Werturteile im Geschichtsunterricht'. Geschichte in Wissenschaft und Unterricht 21 (3): 198-215.

Wertsch, James V. 2008. 'Collective Memory and Narrative Templates'. Social Research 75 (1): 133-156.

Open Access This chapter is licensed under the terms of the Creative Commons Attribution 4.0 International License (http://creativecommons.org/licenses/ by/4.0/), which permits use, sharing, adaptation, distribution and reproduction in any medium or format, as long as you give appropriate credit to the original author(s) and the source, provide a link to the Creative Commons licence and indicate if changes were made.

The images or other third party material in this chapter are included in the chapter's Creative Commons licence, unless indicated otherwise in a credit line to the material. If material is not included in the chapter's Creative Commons licence and your intended use is not permitted by statutory regulation or exceeds the permitted use, you will need to obtain permission directly from the copyright holder.

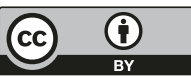

